\title{
Hasil dan Kualitas Okra (Abelmoschus esculentus L. Moench.) Merah dan Okra Hijau dengan Jenis Pupuk yang Berbeda
}

\author{
Yield and Quality of Red and Green Okra (Abelmoschus esculentus $L$. \\ Moench.) with Different Types of Fertilizer
}

\author{
Auhge Eva Sari Manik ${ }^{1,2}$, Maya Melati ${ }^{*}$, Ani Kurniawati ${ }^{3}$, dan Didah Nur Faridah ${ }^{4}$ \\ ${ }^{1}$ Program Studi Agronomi dan Hortikultura, Sekolah Pascasarjana, Institut Pertanian Bogor \\ ${ }^{2}$ Dinas Pertanian dan Ketahanan Pangan Provinsi Nusa Tenggara Timur \\ Jl. Polisi Militer No. 7, Kupang 85111, Nusa Tenggara Timur, Indonesia \\ ${ }^{3}$ Departemen Agronomi dan Hortikultura, Fakultas Pertanian, Institut Pertanian Bogor \\ (Bogor Agricultural University), Jl. Meranti, Kampus IPB Darmaga, Bogor 16680, Indonesia \\ ${ }^{4}$ Departemen Ilmu dan Teknologi Pangan, Fakultas Teknologi Pertanian, Institut Pertanian Bogor \\ (Bogor Agricultural University), Jl. Meranti, Kampus IPB Darmaga, Bogor 16680, Indonesia
}

Diterima 26 Juli 2018/Disetujui 16 November 2018

\begin{abstract}
Okra fruit contains phenolic compounds as natural antioxidant. The aim of this research was to analyze the effect of different types of fertilizers on production and quality of two okra varieties. The experiment was conducted in October 2017 to February 2018 at Bogor Agricultural University experimental field at Leuwikopo, Darmaga, Bogor (-6033'49.3"SL, $\left.106^{\circ} 43^{\prime} 30.7^{\prime \prime} \mathrm{EL}\right)$. The experiment used nested randomized complete block design with 2 factors and 4 replications. The first factor consisted of two okra varieties with different colour (red and green okra). The second factor was fertilizer types consisted of no fertilizer, organic (cow manure), combination of organic + inorganic, and inorganic fertilizer. The results showed that fertilizer types significantly affected plant height and fruit $N$ content but did not affect fruit production. Red okra had a higher plant height, lower number of leaves and leaf $K$ content than those of the green okra. The interaction effect of both factors was significant on total phenolic content in fruit and P content in leaf. The highest total phenolic content in fruit was showed by red okra with inorganic fertilizer, although it was not significantly different to those of red okra with combination organic + inorganic fertilizer, and also to green okra with organic fertilizer. The highest P content in leaf was found in red okra without fertilizer, however it was not significantly different to red okra with combination organic + inorganic fertilizer, green okra with organic fertilizer, and green okra with inorganic fertilizer.
\end{abstract}

Keywords: inorganic fertilizer, leaf nutrient, organic fertilizer, phenolic compound

\section{ABSTRAK}

Buah okra mengandung komponen fenolik yang berperan dalam aktivitas antioksidan. Tujuan penelitian ini adalah menganalisis pengaruh perbedaan jenis pupuk terhadap produksi dan kualitas dua varietas okra. Penelitian dilaksanakan dari bulan Oktober 2017-Februari 2018 di Kebun Percobaan IPB Leuwikopo, Darmaga, Bogor pada -6033'49.3"LS, $106^{\circ} 43^{\prime} 30.7^{\prime \prime} B$. Penelitian menggunakan rancangan acak kelompok lengkap tersarang dengan 2 faktor diulang sebanyak 4 ulangan. Faktor pertama adalah varietas okra terdiri dari okra merah dan okra hijau. Faktor kedua adalah jenis pupuk terdiri dari tanpa pupuk, organik (pupuk kandang sapi), kombinasi organik + anorganik, dan anorganik. Hasil penelitian menunjukkan bahwa jenis pupuk berpengaruh terhadap tinggi tanaman dan kadar $N$ buah, tetapi tidak berpengaruh terhadap produksi buah okra. Tanaman okra merah lebih tinggi namun dengan jumlah daun dan kadar K daun lebih sedikit dibandingkan tanaman okra hijau. Interaksi antara kedua faktor berpengaruh nyata terhadap kadar total fenol buah dan kadar P daun. Kadar total fenol tertinggi terdapat pada buah okra merah dengan pupuk anorganik, namun tidak berbeda nyata dengan kadar total fenol buah okra merah dengan kombinasi organik + anorganik dan kadar total fenol buah okra hijau dengan pupuk organik. Kadar P daun tertinggi terdapat pada tanaman okra merah tanpa pupuk meskipun tidak berbeda nyata dengan kadar P daun okra merah dengan kombinasi organik + anorganik, kadar P daun okra hijau dengan pupuk organik dan kadar P daun okra hijau dengan pupuk anorganik.

Kata kunci: fenolik, hara daun, pupuk anorganik, pupuk organik

* Penulis untuk korespondensi. e-mail: mayamelati14@gmail.com 


\section{PENDAHULUAN}

Okra (Abelmoschus esculentus L. Moench.) merupakan salah satu jenis sayuran fungsional yang termasuk dalam famili Malvaceae, memiliki banyak manfaat bagi kesehatan. Manfaat okra antara lain mencegah diabetes, menurunkan kolesterol, mencegah perkembangan kanker, dan baik untuk sistem pencernaan (Amin, 2011). Okra mengandung protein, karbohidrat, dan lemak (Oyelade et al., 2003; Arapitsas, 2008). Salah satu bagian tanaman okra yang dimanfaatkan adalah buah muda. Buah okra yang sudah tua, rasanya liat dan tidak layak untuk dikonsumsi.

Khomsug et al. (2010); Hu et al. (2013); Mohammed et al. (2016) melaporkan buah okra mengandung senyawa fenolik dan flavonoid. Hamid et al. (2010) berpendapat senyawa fenolik dan flavonoid merupakan antioksidan alami yang lebih aman daripada antioksidan sintetik karena mampu meredam radikal bebas dalam tubuh manusia, sehingga mencegah penyakit degeneratif.

Okra prospektif untuk dikembangkan di Indonesia. Ada dua varietas okra yang dikembangkan di Indonesia yaitu okra merah dan okra hijau. Buah okra termasuk komoditas ekspor. Tahun 2016 buah okra hijau diekspor ke Jepang sebanyak 500 ton (Afandi, 2016).

Pengembangan okra perlu menekankan pada produksi yang tinggi (kuantitas), dan kualitas sesuai tuntutan pasar. Kualitas dapat dilihat dari penampakan (ukuran, warna, bentuk), kandungan gizi serta kandungan bioaktif yang terkandung didalamnya (Abbott, 1999; Hariyadi, 2009).

Jenis pupuk yang berbeda dapat menyebabkan produksi dan kualitas produk yang berbeda. Ibrahim et al. (2013) menunjukkan bahwa kadar total fenol, flavonoid, dan kandungan gula terlarut total pada tanaman kacip fatimah (Labisia pumila) meningkat dengan pemupukan organik. Gashua et al. (2014) menyatakan penggunaan pupuk kandang sapi pada tanaman okra menghasilkan jumlah buah per tanaman, bobot buah, dan produksi lebih baik dibandingkan pupuk kandang kambing. Wibowo et al. (2015) menemukan kombinasi pupuk organik dan anorganik (NPK) dapat meningkatkan produksi daun layak pasar pada tanaman gedi (Abelmoschus manihot). Penelitian ini bertujuan untuk mempelajari pengaruh perbedaan jenis pupuk terhadap produksi dan kualitas dua varietas buah okra, yaitu okra merah (Zahira IPB) dan okra hijau (Naila IPB).

\section{BAHAN DAN METODE}

Percobaan dilaksanakan di Kebun Percobaan IPB Leuwikopo, Darmaga, Bogor pada bulan Oktober 2017 sampai Februari 2018. Analisis tanah, hara pupuk, dan kadar hara $\mathrm{N}, \mathrm{P}$, dan $\mathrm{K}$ tanaman (daun dan buah) dilaksanakan di Laboratorium Pengujian Departemen Agronomi dan Hortikultura dan Laboratorium Departemen Ilmu Tanah dan Sumberdaya Lahan, Fakultas Pertanian, Institut Pertanian Bogor. Analisis kadar total fenol dilaksanakan di Laboratorium Departemen Ilmu dan Teknologi Pangan, Fakultas Teknologi Pertanian, Institut Pertanian Bogor.
Bahan yang digunakan dalam penelitian ini antara lain benih okra merah (varietas Zahira IPB) dan okra hijau (varietas Naila IPB), pupuk organik (pupuk kandang sapi), dan pupuk anorganik (Urea, ZA, SP-36, KCl). Bahan untuk analisis kadar total fenol antara lain etanol, reagen FolinCiocalteau, larutan $\mathrm{NaHCO}_{3}$, dan asam galat. Alat yang digunakan di laboratorium meliputi vortex, spektrofotometer UV-Vis, oven suhu $60^{\circ} \mathrm{C}$.

Rancangan yang digunakan dalam penelitian ini adalah RAKL tersarang (nested design) dengan dua faktor, yaitu varietas okra dan jenis pupuk. Varietas okra terdiri dari okra merah dan okra hijau, sedangkan jenis pupuk terdiri dari tanpa pupuk, pupuk organik (pupuk kandang sapi) dengan dosis 15 ton ha $^{-1}$, kombinasi organik + anorganik (dosis rekomendasi 50\% pupuk organik $+50 \%$ pupuk anorganik), dan pupuk anorganik (200 kg urea ha ${ }^{-1}, 225$ kg ZA ha-1, $120 \mathrm{~kg} \mathrm{SP}^{-36} \mathrm{ha}^{-1}$ dan $150 \mathrm{~kg} \mathrm{KCl} \mathrm{ha}^{-1}$ ). Dosis pupuk anorganik mengacu pada Afandi (2016). Terdapat 2 blok percobaan berdasarkan faktor varietas okra, dengan 4 ulangan. Ulangan tersarang pada faktor varietas okra, faktor jenis pupuk diacak di dalam ulangan tersebut, sehingga terdapat 32 satuan percobaan. Satu unit percobaan terdapat 30 tanaman okra dan setiap unitnya menggunakan 5 tanaman contoh. Seluruh data percobaan dianalisis dengan analisis ragam gabungan untuk membandingkan variabel dengan jenis pupuk dan varietas okra.

Benih disemai menggunakan tray selama 14 hari. Petak yang digunakan sebanyak 32 petak dengan ukuran masing-masing petak $2 \mathrm{~m}$ x $2.4 \mathrm{~m}$. Jarak antar petak $100 \mathrm{~cm}$, jarak antar ulangan $200 \mathrm{~cm}$ dan jarak antara varietas okra $19 \mathrm{~m}$ untuk menghindari polinasi silang antar varietas okra. Pindah tanam dilakukan pada umur 14 hari setelah semai (HSS) atau terbentuk 2 daun sempurna dengan jarak tanam 40 cm x $40 \mathrm{~cm}$ (Nadira et al., 2009). Aplikasi pupuk dilakukan pada saat 5 hari sebelum pindah tanam (HSbP), 15, 40, 65, dan 90 hari setelah pindah tanam (HSP). Pemangkasan daun pada cabang utama dilakukan pada awal generatif (30 HSP) untuk merangsang buah pada cabang-cabang utama.

Umur berbunga $50 \%$ adalah $\pm 35-40 \mathrm{HSP}$, panen buah pada saat 4-6 hari setelah antesis (HSA). Panen okra pertama kali pada umur 46 HSP dari posisi buah ketiga dan seterusnya, yaitu buah dengan panjang 6.5-11 cm (Aguiar et al., 2011; Afandi, 2016). Panen buah dilakukan 1-2 hari sekali sampai 100 HSP, selanjutnya produksi buah sudah berkurang. Jumlah buah okra diakumulasi per minggu dari panen pertama sampai panen terakhir.

Pengamatan tinggi tanaman dan jumlah daun dilaksanakan 2 minggu sekali sejak 2 HSP. Tinggi tanaman diukur sampai 100 HSP sedangkan jumlah daun dihitung sampai 30 HSP. Hal ini disebabkan memasuki awal generatif, daun okra berguguran dan berukuran kecil.

Analisis meliputi kadar hara $\mathrm{N}, \mathrm{P}$, dan $\mathrm{K}$ daun pada awal generatif (30 HSP) dan kadar hara N, P, dan K buah menggunakan metode Kjeldahl untuk N, metode pengabuan basah untuk P dan K. Analisis kadar total fenol (Benites et al., 2015) dengan pengekstrak etanol. Sampel buah untuk analisis kadar hara $\mathrm{N}, \mathrm{P}$, dan $\mathrm{K}$ buah dan analisis kadar total fenol menggunakan buah yang sudah dikeringkan dalam 
oven pada suhu $60{ }^{\circ} \mathrm{C}$ selama tiga hari sampai kadar air konstan.

Data dianalisis menggunakan uji F, apabila diperoleh hasil yang berbeda nyata dilakukan uji lanjut dengan Duncan Multiple Range Test (DMRT) pada taraf $\alpha=5 \%$.

\section{HASIL DAN PEMBAHASAN}

\section{Kondisi Umum}

Kadar hara tanah lokasi penelitian okra merah dan okra hijau relatif berbeda (Tabel 1). Kadar hara N, P dan K di dalam tanah di akhir penelitian relatif cukup tinggi.

\section{Pertumbuhan Tanaman}

Pemberian pupuk meningkatkan tinggi tanaman okra pada 100 HSP (Tabel 2). Pemberian pupuk organik dan pupuk anorganik mampu meningkatkan tinggi tanaman yang sama, karena kedua jenis pupuk memiliki kelebihan masing-masing. Pupuk organik berperan meningkatkan ketersediaan unsur hara karena dapat meningkatkan bahan organik tanah (Melati et al., 2008), sedangkan hara dengan pupuk anorganik lebih cepat diserap oleh tanaman (Adil et al., 2006) sehingga dapat mendukung pertumbuhan tinggi tanaman. Peningkatan tinggi tanaman diduga berkaitan dengan nilai kadar $\mathrm{N}$ daun yang relatif lebih tinggi dari kedua jenis pupuk dibandingkan perlakuan lainnya (Tabel 3). Pertumbuhan vegetatif tanaman khususnya pertumbuhan batang yang mampu memacu pertumbuhan tinggi tanaman terung dipengaruhi oleh ketersediaan unsur hara dalam tanah terutama nitrogen (Firmansyah et al., 2017).

Tanaman okra merah lebih tinggi daripada tanaman okra hijau, namun dengan jumlah daun yang lebih sedikit (Tabel 2) menunjukkan ruas pada batang tanaman okra merah lebih panjang daripada tanaman okra hijau. Jumlah daun okra pada awal generatif berkisar 12-15 helai (Tabel 2), setelah itu daun okra gugur dengan sendirinya disertai dengan pemanenan buah yang sudah layak dikonsumsi.

Tabel 1. Hasil analisis tanah awal okra merah dan okra hijau

\begin{tabular}{lcccc}
\hline \multirow{2}{*}{ Parameter tanah } & \multicolumn{2}{c}{ Nilai } & \multicolumn{2}{c}{ Status* } \\
\cline { 2 - 5 } & Okra merah & Okra hijau & Okra merah & Okra hijau \\
\hline $\mathrm{KTK}(\mathrm{cmol}(+) / \mathrm{kg})$ & 19.41 & 19.45 & sedang & sedang \\
$\mathrm{pH}\left(\mathrm{H}_{2} \mathrm{O}\right)$ & 5.20 & 6.20 & masam & agak masam \\
$\mathrm{C}-$ Organik $(\%)$ & 1.49 & 1.57 & rendah & rendah \\
$\mathrm{N}$ Total $(\%)$ & 0.23 & 0.20 & sedang & rendah \\
P Total $\left(\mathrm{mg} \mathrm{P}_{2} \mathrm{O}_{5} / 100 \mathrm{~g}\right)$ & 180.14 & 166.88 & sangat tinggi & sangat tinggi \\
P Tersedia $\left(\mathrm{P}_{2} \mathrm{O}_{5} \mathrm{ppm}\right)$ & 57.81 & 123.16 & sangat tinggi & sangat tinggi \\
$\mathrm{K}$ Total $\left(\mathrm{mg} \mathrm{K} \mathrm{K}_{2} \mathrm{O} / 100 \mathrm{~g}\right)$ & 39.48 & 17.05 & sedang & rendah \\
$\mathrm{K}$ dd $(\mathrm{cmol}(+) / \mathrm{kg})$ & 0.53 & 0.43 & sedang & sedang \\
\hline
\end{tabular}

Keterangan: *berdasarkan kriteria Balai Penelitian Tanah (Sulaeman et al., 2005).

Tabel 2. Pengaruh jenis pupuk dan varietas okra terhadap tinggi tanaman (100 HSP) dan jumlah daun (30 HSP)

\begin{tabular}{lcc}
\hline Perlakuan & Tinggi tanaman $(\mathrm{cm})$ & Jumlah daun (helai) \\
\hline Jenis pupuk & $140.6 \pm 5.8 \mathrm{~b}$ & $12.9 \pm 0.7$ \\
Tanpa pupuk & $158.4 \pm 6.7 \mathrm{a}$ & $13.3 \pm 0.8$ \\
Pupuk organik & $146.5 \pm 3.4 \mathrm{~b}$ & $13.0 \pm 0.4$ \\
Pupuk organik + anorganik & $148.0 \pm 7.2 \mathrm{ab}$ & $14.6 \pm 0.7$ \\
Pupuk anorganik & $*$ & tn \\
\hline Uji F & $159.2 \pm 2.8 \mathrm{a}$ & $12.3 \pm 0.3 \mathrm{~b}$ \\
\hline Varietas okra & $137.5 \pm 3.9 \mathrm{~b}$ & $14.6 \pm 0.4 \mathrm{a}$ \\
Okra merah & $* *$ & $* *$ \\
Okra hijau & tn & tn \\
\hline Uji F & \multicolumn{1}{l}{ tn } & \\
\hline Interaksi & & \\
\hline
\end{tabular}

Keterangan: Angka yang diikuti oleh huruf yang sama pada kolom yang sama menunjukkan tidak berbeda nyata menurut uji DMRT pada taraf $\alpha=5 \%$ pada perbedaan antar jenis pupuk, nilai rataan diikuti oleh nilai standard error $(\mathrm{SE})$; $\mathrm{tn}=$ tidak nyata, $*=$ berbeda nyata pada taraf $5 \%, * *=$ berbeda nyata pada taraf $1 \%$; HSP $=$ hari setelah pindah tanam. 


\section{Produksi Tanaman}

Produksi buah okra per tanaman dan per petak (baik jumlah dan bobot buah) tidak dipengaruhi oleh perbedaan jenis pupuk (Tabel 4 dan 5). Hal ini dimungkinkan kadar hara daun pada awal generatif pada setiap perlakuan relatif hampir sama (Tabel 3 dan 6) sehingga pertumbuhan tanaman dan hasil produksi relatif tidak berbeda nyata.

Tabel 4 memperlihatkan tidak ada perbedaan yang nyata antar varietas okra, namun ada indikasi jumlah buah per tanaman lebih banyak dihasilkan oleh tanaman okra hijau. Hal ini mungkin disebabkan kemampuan tanaman okra hijau menyerap hara $\mathrm{N}$ dan $\mathrm{K}$ lebih tinggi daripada tanaman okra merah, karena kadar $\mathrm{N}$ daun dan $\mathrm{K}$ daun pada tanaman okra hijau cenderung lebih tinggi dibandingkan okra merah (Tabel 3). Salah satu peran unsur kalium adalah untuk memacu translokasi asimilat dari sumber (daun) ke bagian organ penyimpanan (sink), dalam hal ini buah (Marschner, 2012). Hal ini memungkinkan tanaman okra hijau yang memiliki jumlah daun lebih banyak (Tabel 2) dapat menghasilkan buah per tanaman lebih banyak. Buah okra muncul pada setiap ketiak daun, dan pada ketiak daun yang sama tidak akan muncul buah lagi, namun muncul pada ketiak daun di atasnya.

Tabel 5 juga memperlihatkan tidak terdapat perbedaan nyata antar varietas okra, namun ada indikasi tanaman okra merah menghasilkan jumlah buah per petak lebih banyak karena tanaman okra merah lebih dulu berbunga dan umur produksi lebih panjang dibandingkan okra hijau serta keragaan tanaman okra merah di lapangan lebih baik.

Tabel 3. Pengaruh jenis pupuk dan varietas okra terhadap kadar $\mathrm{N}$ dan $\mathrm{K}$ daun pada awal generatif (30 HSP)

\begin{tabular}{|c|c|c|}
\hline \multirow{2}{*}{ Perlakuan } & \multicolumn{2}{|c|}{ Kadar hara daun $(\%)^{x}$} \\
\hline & $\mathrm{N}$ & $\mathrm{K}$ \\
\hline \multicolumn{3}{|l|}{ Jenis pupuk } \\
\hline Tanpa pupuk & $4.95 \pm 0.10$ & $3.53 \pm 0.25$ \\
\hline Pupuk organik & $5.10 \pm 0.07$ & $3.52 \pm 0.11$ \\
\hline Pupuk organik + anorganik & $5.06 \pm 0.09$ & $3.63 \pm 0.19$ \\
\hline Pupuk anorganik & $5.07 \pm 0.11$ & $3.46 \pm 0.21$ \\
\hline Uji F & $\operatorname{tn}$ & $\operatorname{tn}$ \\
\hline \multicolumn{3}{|l|}{ Varietas okra } \\
\hline Okra merah & $4.98 \pm 0.07$ & $3.30 \pm 0.14 b$ \\
\hline Okra hijau & $5.10 \pm 0.06$ & $3.77 \pm 0.10 \mathrm{a}$ \\
\hline Uji F & tn & $*$ \\
\hline Interaksi & $\operatorname{tn}$ & tn \\
\hline
\end{tabular}

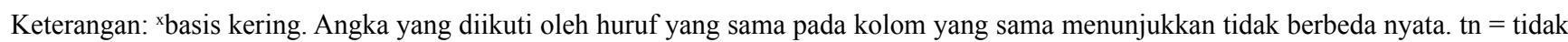
nyata, $*$ = berbeda nyata pada taraf $5 \%$. Nilai rataan diikuti oleh nilai standard error (SE); HSP $=$ hari setelah pindah tanam.

Tabel 4. Rataan jumlah buah dan produksi buah per tanaman pada berbagai jenis pupuk dan antar varietas okra

\begin{tabular}{lcc}
\hline Perlakuan & Jumlah buah (buah) & Total bobot buah $(\mathrm{g})$ \\
\hline Jenis pupuk & $21.6 \pm 0.7$ & $228.73 \pm 10.9$ \\
Tanpa pupuk & $24.4 \pm 1.0$ & $272.60 \pm 14.7$ \\
Pupuk organik & $22.8 \pm 1.1$ & $251.20 \pm 11.6$ \\
Pupuk organik + anorganik & $23.1 \pm 0.5$ & $253.68 \pm 3.3$ \\
Pupuk anorganik & tn & tn \\
\hline Uji F & $22.3 \pm 0.6$ & $249.75 \pm 5.9$ \\
\hline Varietas okra & $23.7 \pm 0.7$ & $253.36 \pm 10.4$ \\
Okra merah & tn & tn \\
Okra hijau & tn & tn \\
\hline Uji F & Interaksi &
\end{tabular}

Keterangan: nilai rataan diikuti oleh nilai standard error $(\mathrm{SE})$; $\mathrm{tn}=$ tidak nyata. 
Tabel 5. Rataan hasil buah total dan hasil buah layak pasar serta potensi hasil layak pasar pada berbagai jenis pupuk dan antar varietas okra

\begin{tabular}{|c|c|c|c|c|c|}
\hline \multirow[t]{2}{*}{ Perlakuan } & \multicolumn{2}{|c|}{$\begin{array}{l}\text { Hasil buah total } \\
\left.\text { (per } 1.92 \mathrm{~m}^{2}\right)\end{array}$} & \multicolumn{2}{|c|}{$\begin{array}{l}\text { Hasil buah layak pasar } \\
\left.\text { (per } 1.92 \mathrm{~m}^{2}\right)\end{array}$} & \multirow{2}{*}{$\begin{array}{l}\text { Potensi hasil } \\
\text { layak pasar } \\
\left(\text { ton } \mathrm{ha}^{-1}\right)^{1)}\end{array}$} \\
\hline & Jumlah buah & Bobot buah (kg) & Jumlah buah & Bobot buah (kg) & \\
\hline \multicolumn{6}{|l|}{ Jenis pupuk } \\
\hline Kontrol & $185.0 \pm 11.3$ & $1.98 \pm 0.15$ & $173.4 \pm 10.9$ & $1.82 \pm 0.13$ & $9.50 \pm 0.70$ \\
\hline $\mathrm{PO}$ & $206.8 \pm 13.5$ & $2.30 \pm 0.17$ & $192.3 \pm 12.4$ & $2.09 \pm 0.14$ & $10.90 \pm 0.74$ \\
\hline $\mathrm{PO}+\mathrm{PA}$ & $193.6 \pm 12.9$ & $2.17 \pm 0.15$ & $183.9 \pm 13.1$ & $2.03 \pm 0.15$ & $10.56 \pm 0.80$ \\
\hline PA & $203.5 \pm 12.4$ & $2.26 \pm 0.14$ & $192.0 \pm 10.7$ & $2.10 \pm 0.11$ & $10.90 \pm 0.58$ \\
\hline Uji F & tn & tn & tn & tn & tn \\
\hline \multicolumn{6}{|l|}{ Varietas okra } \\
\hline Okra merah & $204.6 \pm 7.3$ & $2.30 \pm 0.08$ & $193.3 \pm 7.0$ & $2.13 \pm 0.08$ & $11.12 \pm 0.40$ \\
\hline Okra hijau & $189.8 \pm 9.8$ & $2.06 \pm 0.12$ & $177.4 \pm 9.0$ & $1.88 \pm 0.10$ & $9.81 \pm 0.54$ \\
\hline Uji F & tn & tn & tn & tn & $\operatorname{tn}$ \\
\hline Interaksi & tn & tn & tn & tn & tn \\
\hline
\end{tabular}

Keterangan: ${ }^{1)}$ Asumsi populasi 62,500 tanaman per ha. Potensi hasil layak pasar dihitung dari bobot buah per $1.92 \mathrm{~m}^{2}$ dikalikan dengan 10,000/1.92. Kontrol = tanpa pupuk, $\mathrm{PO}=$ pupuk organik, $\mathrm{PA}=$ pupuk anorganik, $\mathrm{tn}=$ tidak nyata. Nilai rataan diikuti oleh nilai standard error (SE).

\section{Kadar Hara Daun Okra}

Jenis pupuk tidak berpengaruh nyata terhadap kadar hara $\mathrm{N}$ dan $\mathrm{K}$ daun pada awal generatif (Tabel 3). Ada indikasi pemberian pupuk meningkatkan kadar $\mathrm{N}$ daun dan tanaman okra hijau memiliki kadar $\mathrm{K}$ daun lebih tinggi dibandingkan tanaman okra merah. Penyerapan hara pada okra hijau dapat lebih tinggi karena $\mathrm{pH}$ tanah pada lokasi okra hijau lebih tinggi dibandingkan pada lokasi okra merah (Tabel 1).

Pengaruh interaksinyata antara jenis pupuk dan varietas okra terhadap kadar P daun (Tabel 6), yaitu pemberian pupuk menurunkan kadar P daun pada okra merah (9.43-18.87\%), namun tidak berpengaruh terhadap kadar $\mathrm{P}$ daun pada okra hijau. Kadar P daun tertinggi terdapat pada tanaman okra merah tanpa pupuk namun tidak berbeda nyata dengan kadar P daun okra merah dengan kombinasi organik + anorganik, kadar P daun okra hijau dengan pupuk organik, dan kadar $\mathrm{P}$ daun okra hijau dengan pupuk anorganik. Tanah pada lokasi okra merah bersifat masam dan kadar P dalam tanah sudah sangat tinggi (Tabel 1) sehingga mungkin pupuk fosfat yang diberikan tidak efisien justru menurunkan kadar $\mathrm{P}$ pada tanaman okra merah karena $\mathrm{P}$ terikat pada $\mathrm{Fe}$ atau Al sehingga menjadi tidak tersedia bagi tanaman. Sari et al. (2017) berpendapat fosfor (P) dapat tersedia dengan penambahan bahan organik karena asam organik hasil dari dekomposisi bahan organik memiliki kemampuan mengikat kation seperti Al dan Fe melalui ikatan khelasi. Hal ini memungkinkan kadar $\mathrm{P}$ daun pada tanaman okra merah dengan pupuk organik dan kombinasi organik + anorganik relatif lebih tinggi dibandingkan dengan pupuk anorganik (Tabel 6).

\section{Kadar Hara Buah dan Kadar Total Fenol Buah}

Jenis pupuk berpengaruh terhadap kadar $\mathrm{N}$ buah, tetapi tidak berpengaruh terhadap kadar $\mathrm{P}$ dan $\mathrm{K}$ buah (Tabel 7). Pemberian pupuk meningkatkan kadar N buah. Pupuk

Tabel 6. Interaksi antara jenis pupuk dan varietas okra terhadap kadar P daun pada awal generatif (30 HSP)

\begin{tabular}{lll}
\hline \multirow{2}{*}{ Perlakuan } & \multicolumn{2}{c}{ Kadar P daun (\%)* } \\
\cline { 2 - 3 } & Okra merah & Okra hijau \\
\hline Tanpa pupuk & $0.53 \pm 0.02 \mathrm{a}$ & $0.47 \pm 0.01 \mathrm{bc}$ \\
Pupuk organik & $0.46 \pm 0.01 \mathrm{bc}$ & $0.50 \pm 0.01 \mathrm{ab}$ \\
Pupuk organik + anorganik & $0.48 \pm 0.03 \mathrm{ab}$ & $0.48 \pm 0.01 \mathrm{bc}$ \\
Pupuk anorganik & $0.43 \pm 0.02 \mathrm{c}$ & $0.49 \pm 0.01 \mathrm{ab}$ \\
\hline
\end{tabular}

Keterangan: *basis kering. Angka yang diikuti huruf yang sama menunjukkan tidak berbeda nyata berdasarkan uji DMRT pada taraf $\alpha=$ $5 \%$, nilai rataan diikuti oleh nilai standard error $(\mathrm{SE}) ; \mathrm{HSP}=$ hari setelah pindah tanam. 
anorganik menghasilkan kadar $\mathrm{N}$ buah tertinggi meskipun tidak berbeda nyata dengan perlakuan kombinasi organik + anorganik. Hal ini dapat disebabkan karena hara dari pupuk anorganik lebih mudah tersedia dan dapat diserap lebih cepat oleh tanaman. Buah okra merah memiliki kadar $\mathrm{N}$ buah cenderung lebih tinggi dan kadar $\mathrm{P}$ dan $\mathrm{K}$ buah lebih rendah dibandingkan buah okra hijau $(\mathrm{p}>0.05)$.

Gambar 1 menunjukkan interaksi antara jenis pupuk dan varietas okra berpengaruh nyata terhadap kadar total fenol buah. Pemberian pupuk meningkatkan kadar total fenol buah okra merah dan buah okra hijau. Kadar total fenol tertinggi terdapat pada buah okra merah dengan pupuk anorganik, namun tidak berbeda nyata dengan kadar total fenol buah okra merah dengan kombinasi organik + anorganik dan kadar total fenol buah okra hijau dengan pupuk organik. Hal ini menunjukkan adanya tanggap yang berbeda antar varietas terhadap pemupukan. Ketersediaan unsur hara berpengaruh terhadap produksi senyawa fenolik. Stewart et al. (2001) berpendapat nitrogen memodulasi biosintesis metabolit sekunder seperti senyawa fenol, glucosinate, dan karotenoid. Unsur $\mathrm{N}$ berperan dalam sintesis asam amino dalam pembentukan senyawa fenolik dari lintasan asam sikimat dan fenil propanoid (Morton, 2013).

Peningkatan kadar total fenol buah (Gambar 1) diduga ada kaitannya dengan peningkatan kadar $\mathrm{N}$ dalam buah (Tabel 7). Ketersediaan hara dari pupuk anorganik lebih mudah memungkinkan penyerapan $\mathrm{N}$ tanaman lebih baik. Menurut Mualim et al. (2012), pemberian pupuk anorganik pada kolesom menyebabkan kandungan total fenolik lebih baik dibandingkan yang diberi pupuk organik di musim

Tabel 7. Pengaruh jenis pupuk dan varietas okra terhadap kadar hara buah panen minggu ke-2 umur 54-61 HSP

\begin{tabular}{|c|c|c|c|}
\hline \multirow{2}{*}{ Perlakuan } & \multicolumn{3}{|c|}{ Kadar hara buah $(\%)^{\mathrm{x}}$} \\
\hline & $\mathrm{N}$ & $\mathrm{P}$ & $\mathrm{K}$ \\
\hline \multicolumn{4}{|l|}{ Jenis pupuk } \\
\hline Tanpa pupuk & $3.17 \pm 0.06 b$ & $0.57 \pm 0.01$ & $3.58 \pm 0.19$ \\
\hline Pupuk organik & $3.21 \pm 0.06 \mathrm{~b}$ & $0.57 \pm 0.01$ & $3.74 \pm 0.17$ \\
\hline Pupuk organik + anorganik & $3.29 \pm 0.04 \mathrm{ab}$ & $0.56 \pm 0.01$ & $3.67 \pm 0.14$ \\
\hline Pupuk anorganik & $3.38 \pm 0.03 \mathrm{a}$ & $0.56 \pm 0.01$ & $3.65 \pm 0.15$ \\
\hline Uji F & $*$ & tn & $\operatorname{tn}$ \\
\hline \multicolumn{4}{|l|}{ Varietas okra } \\
\hline Okra merah & $3.31 \pm 0.03$ & $0.56 \pm 0.00$ & $3.50 \pm 0.11$ \\
\hline Okra hijau & $3.21 \pm 0.04$ & $0.57 \pm 0.01$ & $3.82 \pm 0.10$ \\
\hline Uji F & tn & tn & $\operatorname{tn}$ \\
\hline Interaksi & th & th & $\operatorname{tn}$ \\
\hline
\end{tabular}

Keterangan: ${ }^{x}$ basis kering. Angka yang diikuti oleh huruf yang sama pada kolom yang sama menunjukkan tidak berbeda nyata menurut uji DMRT pada taraf $\alpha=5 \%$ pada perbedaan antar jenis pupuk. $\mathrm{tn}=$ tidak nyata; $*=$ berbeda nyata pada taraf $5 \%$. Nilai rataan diikuti oleh nilai standard error $(\mathrm{SE}) ; \mathrm{HSP}=$ hari setelah pindah tanam.

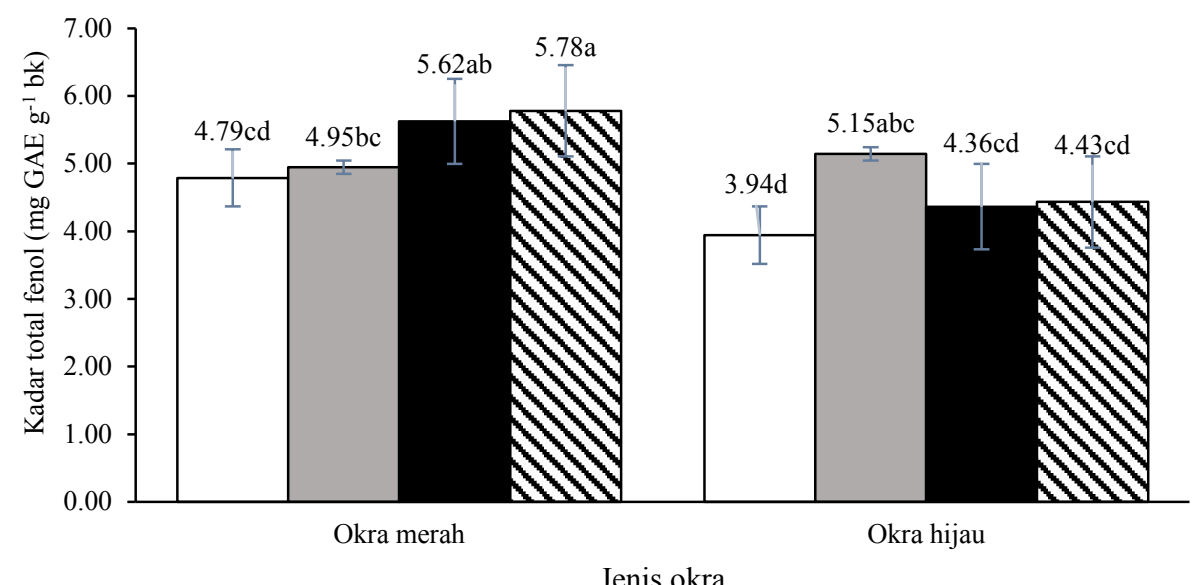

$\square$ Kontrol $\square \mathrm{PO} \quad \square \mathrm{PO}+\mathrm{PA} \quad \mathbf{P A}$

Gambar 1. Interaksi antara jenis pupuk dan varietas okra terhadap kadar total fenol buah okra. GAE = gallic acid equivalent; bk $=$ basis kering; Kontrol = tanpa pupuk; $\mathrm{PO}=$ pupuk organik; $\mathrm{PA}=$ pupuk anorganik. Bar $+/$ - standard error $(\mathrm{SE})$ 
hujan. Aplikasi pupuk organik juga dapat meningkatkan ketersediaan nitrogen dikarenakan pupuk organik berperan dalam perbaikan sifat kimia tanah dalam kaitannya dengan dekomposisi bahan organik, yaitu perubahan terhadap komposisi kimia bahan organik dari senyawa yang kompleks menjadi senyawa yang lebih sederhana. Nutrisi dalam pupuk organik melalui proses mineralisasi dapat mempertahankan tingkat tanah yang optimal selama jangka waktu yang lama. Beberapa zat organik yang dilepaskan selama mineralisasi dapat bertindak sebagai kelat yang membantu dalam penyerapan besi dan mikro-nutrisi lainnya sehingga dapat meningkatkan pertumbuhan dan kualitas tanaman (Mary dan Nithiya, 2015). Kurniawan et al. (2014) berpendapat semakin besar ketersediaan nitrogen dengan peningkatan dosis pupuk organik, semakin besar pula kadar fenolik pada biji tanaman kedelai. Mary dan Nithiya (2015) menunjukkan bahwa pemupukan organik meningkatkan senyawa fitokimia (alkaloid, flavonoid, tanin, saponin, dan total fenol) tanaman Solanum nigrum dibandingkan pemupukan anorganik.

Gambar 1 memperlihatkan rata-rata kadar total

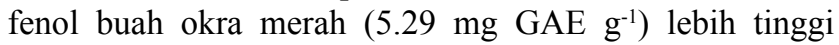
dibandingkan buah okra hijau (4.47 $\mathrm{mg} \mathrm{GAE} \mathrm{g}^{-1}$ ) dengan kadar $\mathrm{N}$ buah okra merah lebih tinggi dibandingkan kadar $\mathrm{N}$ buah okra hijau (Tabel 7).

\section{KESIMPULAN}

Pupuk anorganik maupun pupuk organik dapat digunakan untuk meningkatkan produksi dan kualitas buah okra. Pemberian pupuk anorganik maupun pupuk organik mampu meningkatkan tinggi tanaman okra. Tanaman okra hijau lebih pendek namun dengan jumlah daun lebih banyak dibandingkan tanaman okra merah. Produksi buah okra hijau dan okra merah relatif sama, akan tetapi umur produksi okra merah lebih panjang. Pengaruh interaksi nyata pada kadar total fenol buah okra. Kadar total fenol buah okra merah diperoleh dengan pemberian pupuk anorganik, sedangkan kadar total fenol buah okra hijau dengan pemberian pupuk organik.

\section{DAFTAR PUSTAKA}

Abbott, J.A. 1999. Quality measurement of fruits and vegetables. Postharvest Biol. Tec. 15:207-225.

Adil, W.H., N. Sunarlim, I. Roostika. 2006. Pengaruh tiga jenis pupuk nitrogen terhadap tanaman sayuran. Biodiversitas 7:77-80.

Afandi, A.L. 2016. Pengaruh pemberian dosis pupuk urea pada beberapa galur terhadap pertumbuhan, hasil, dan kualitas okra (Abelmoschus esculentus). Skripsi. Program Studi Agroteknologi. Fakultas Pertanian. Universitas Jember. Jember.

Aguiar, J.L., M. McGiffen, E. Natwick, E. Takele. 2011. Okra Production in California. Agriculture and Natural Resources. University of California. California.
Amin, I.M. 2011. Nutritional properties of Abelmoschus esculentus as remedy to manage diabetes mellitus: a literature review. International Conference on Biomedical Engineering and Technology 11:50-54.

Arapitsas, P. 2008. Identification and quantification of polyphenolic compounds from okra seeds and skins. Food Chem. 110:1041-1045.

Benites, R.S.R., A.S.N. Formagio, E.J.S. Argandona, C.R.F. Volobuff, L.N.F. Trevizan, M.C. Vieira, M.S. Silva. 2015. Contents of constituents and antioxidant activity of seed and pulp extracts of Annona coriacea and Annona sylvatica. Braz. J. Biol. 75:685-691.

Firmansyah, I., M. Syakir, L. Lukman. 2017. Pengaruh kombinasi dosis pupuk $\mathrm{N}, \mathrm{P}$, dan $\mathrm{K}$ terhadap pertumbuhan dan hasil tanaman terung (Solanum melongena L.). J. Hort. 27:69-78.

Gashua, A.G., T.T. Bello, S.G. Mohammed, I.B. Mohammed, A. Shehu. 2014. Response of okra [Abelmoschus esculantus (L) Moench] to different sources and levels of organic manure in Sudan Savanna of Nigeria. Int. J. Res. Agric. Food Sci. 2:9-15.

Hamid, A.A., O.O. Aiyelaagbe, L.A. Usman, O.M. Ameen, A. Lawal. 2010. Antioxidants: its medicinal and pharmacological applications. African J. Pure Appl. Chem. 4:142-151.

Hariyadi, P. 2009. Mutu buah (dan sayuran). Foodreview Indonesia 4:16-19.

Hu, S., C. Yuan, C. Zhang, P. Wang, Q. Li, J. Wan, H. Chang, J. Ye, X. Guo. 2013. Comparative study of total flavonoid contents from the different tissues and varieties of Abelmoschus esculentus. Int. J. Med. Sci. Biotechnol. 1:26-30.

Ibrahim, M.H., H.Z.E. Jaafar, E. Karimi, A. Ghasemzadeh. 2013. Impact of organic and inorganic fertilizers application on the phytochemical and antioxidant activity of kacip fatimah (Labisia pumila Benth). Molecules 18:10973-10988.

Khomsug, P., W. Thongjaroenbuangam, N. Pakdeenarong, M. Suttajit, P. Chantiratikul. 2010. Antioxidative activities and phenolic content of extracts from okra (Abelmoschus esculentus L.). Res. J. Biol. Sci. 5:310313.

Kurniawan I.D., R. Soedradjad, A. Syamsunihar. 2014. Pengaruh dosis pupuk organik terhadap kandungan fenolik dan flavonoid biji tanaman kedelai yang berasosiasi dengan Synechococcus sp. Berkala Ilmiah Pertanian 10:1-3. 
Marschner, P. 2012. Marschner's Mineral Nutrition of Higher Plants. Academic Press, San Diego, USA.

Mary, J.A.L., T. Nithiya. 2015. Effect of organic and inorganic fertilizer on growth, phenolic compounds and antioxidant activity of Solanum nigrum L. World J. Pharm. Pharm. Sci. 4:808-822.

Melati, M., A. Asiah, D. Rianawati. 2008. Aplikasi pupuk organik dan residunya untuk produksi kedelai panen muda. Bul. Agron. 36:204-213.

Mohammed, M.I., A.S. Bayero, U.I. Shettima. 2016. Levels of total phenolic and flavonoids in Abelmoschus esculentus L. from some irrigation areas of Kano State-Nigeria. Bayero J. Pure Appl. Sci. 9:121-124.

Morton, A.R. 2013. Kiwifruit (Actinidia spp.) vine and fruit responses to nitrogen fertiliser applied to the soil or leaves. Thesis. Massey University. Palmerston North, New Zealand.

Mualim L., S.A. Aziz, S. Susanto, M. Melati. 2012. Aplikasi pupuk inorganik meningkatkan produksi dan kualitas pucuk kolesom pada musim hujan. J. Agron. Indonesia 40:160-166.

Nadira, S., B. Hatidjah, Nuraeni. 2009. Pertumbuhan dan hasil tanaman okra (Abelmoschus esculantus) pada pelakuan pupuk dekaform dan defoliasi. J. Agrisains 10:10-15.

Oyelade, O.J., B.I.O. Ade-Omowaye, V.F. Adeomi. 2003. Influence of variety on protein, fat contents and some physical characteristics of okra seeds. J. Food Engineering 57:111-114.

Sari, M.N., Sudarsono, Darmawan. 2017. Pengaruh bahan organik terhadap ketersediaan fosfor pada tanahtanah kaya Al dan Fe. Bul. Tanah dan Lahan 1:6571.

Stewart, A.J., W. Chapman, G.I. Jenkins, I. Graham, T. Martin, A. Crozier. 2001. The effect of nitrogen and phosphorus deficiency on flavonol accumulation in plant tissues. Plant Cell Environ. 24:1189-1197.

Sulaeman, Suparto, Eviati. 2005. Petunjuk Teknis Analisis Kimia Tanah, Tanaman, Air, dan Pupuk. Balai Penelitian Tanah. Badan Penelitian dan Pengembangan Pertanian. Departemen Pertanian RI, ID.

Wibowo, R.H., A.D. Susila, J.G. Kartika. 2015. Peningkatan pertumbuhan dan hasil tanaman gedi [Abelmoschus manihot (L.) Medik.] melalui aplikasi pupuk organik dan pupuk anorganik. Bul. Agrohorti 3:193-202. 